UCRL-CR-115743

P.O. \#B192560

\title{
Monthly Report to LLNL from the Budker INP. Novosibirsk, September, 1992
}

\author{
A.A. Ivanov
}

I.A. Kotelnikov

September 1992

\section{DISCLAIMER}

This report was prepared as an account of work sponsored by an agency of the United States Government. Neither the United States Government nor any agency thereof, nor any of their employees, makes any warranty, express or implied, or assumes any legal liability or responsibility for the accuracy, completeness, or usefulness of any information, apparatus, product, or process disclosed, or represents that its use would not infringe privately owned rights. Reference herein to any specific commercial product, process, or service by trade name, trademark, manufacturer, or otherwise does not necessarily constitute or imply its endorsement, recommendation, or favoring by the United States Government or any agency thereof. The views and opinions of authors expressed herein do not necessarily state or reflect those of the United States Government or any agency thereof. 


\section{DISCLAIMER}

This report was prepared as an account of work sponsored by an agency of the United States Government. Neither the United States Government nor any agency thereof, nor any of their employees, make any warranty, express or implied, or assumes any legal liability or responsibility for the accuracy, completeness, or usefulness of any information, apparatus, product, or process disclosed, or represents that its use would not infringe privately owned rights. Reference herein to any specific commercial product, process, or service by trade name, trademark, manufacturer, or otherwise does not necessarily constitute or imply its endorsement, recommendation, or favoring by the United States Government or any agency thereof. The views and opinions of authors expressed herein do not necessarily state or reflect those of the United States Government or any agency thereof. 


\section{DISCLAIMER}

Portions of this document may be illegible in electronic image products. Images are produced from the best available original document. 


\section{Monthly Report to LLNL from the Budker INP. Novosibirsk, September, 1992}

\section{Experimental activity. A.A.Ivanov}

The experiments on a plasma equilibrium response to externally applied disturbance of the magnetic field of a dipole type have been done on the GDT facility. The disturbance was produced by a pair of the coils installed at the end tank so as it was localized in the expander region. The results were compared with the theoretical predictions based on a hydromagnetic model of plasma equilibrium in the magnetic field treated in a long thin approximation. It was found that the measured displacements of the plasma column from a geometrical axis of the device varies linearly with the current in the disturbing coils at least up to $5 \mathrm{~cm}$ at the midplane. The data was processed to subtract the displacement measured for zero current that apparently caused by a small disturbance of the magnetic field by soft-iron-made parts of the equipment placed near the device inside the experimental hall and, in part, also by misalignments of the main coils. Theoretically predicted slope of the displacement-field amplitude dependence is to be inversely proportional to a pressure-weighted curvature averaged along the device. We believe this allows the use of the data for the measurements of this value. The slopes have been calculated for the GDT parameters under different assumptions on $\kappa \rho$ parameter that define an upper limit of integration of the pressure-weighted curvature in the near-end wall region in the expanders. This region contributes strongly to the averaged curvature as the magnetic field here is as small as a 
few gausses. The $\kappa \rho=0.3$ provides the most suitable fit to the experimental data that is in a good agreement with our previous experimental estimations of the averaged curvature. The commissioning of new coils is now coming to the end at the INP machine shop. These smaller size coils will be installed inside the end tank in early november 1992. By making use of these coils we are planning to perform the experiments with quadrupole disturbances of the plasma equilibrium.

\section{Theoretical activity. I.A.Kotelnikov}

Theoretical efforts were focused on formulating of the generalized energy principle for the plasma containing fastly drifting particles. Particularly, the cases of a mirror device with disclike population of fast particles and of a cusp configuration have been considered, with the account of non-paraxiality effects. 